\title{
International Journal of Sciences
}

\section{Research Article}

Volume 9 - June 2020 (06)

\section{Mitochondrial DNA Haplogroup of the Queen Marie-Antoinette (1755-1793)}

\section{Gérard Lucotte $^{1}$, Thierry Thomasset ${ }^{2}$}

${ }^{1}$ Institut d'Anthropologie Moléculaire, 75005 Paris, France

${ }^{2}$ Service d'Analyses Physico-Chimiques, UTC, 50201 Compiègne, France

Abstract: We have studied by SEM-EDX some hairs from a lock of hair of the Queen Marie-Antoinette kept in a medallion. These hairs are thin and of ash blond colour. The mtDNA haplogroup of these hairs is a rare sub-clade of $\mathrm{H}$, characterized by mutations 152C, 194T, 263G, and 315.1 C in the HVR2 region of the mtDNA sequence.

Keywords: Mitochondrial DNA, Haplogroup, Queen Marie-Antoinette

Marie-Antoinette was born in Vienna, on November 2,1755 ; she was one of the daughters of the Austrian Empress Marie-Thérèse. In 1770 Marie-Antoinette was married to the heir to the French throne, the future Louis XVI. She had four children : MarieThérèse Charlotte, Louis Joseph Xavier François, Louis-Charles (the future Louis XVII) and Sophie. Marie-Antoinette died beheaded on October 16, 1793 in Paris, during the French Revolution.

We have obtained from her latest owner information concerning a medallion (Figure 1) that contains Marie-Antoinette's hair. The medallion parts and some hairs were studied by SEM (Scanning Electron Microscopy) and EDX (Energy Dispersive X-ray Spectroscopy) analysis. After DNA extraction from two of these hairs, we have obtained - for the first time to our knowledge - the mitochondrial DNA haplogroup of Marie-Antoinette.

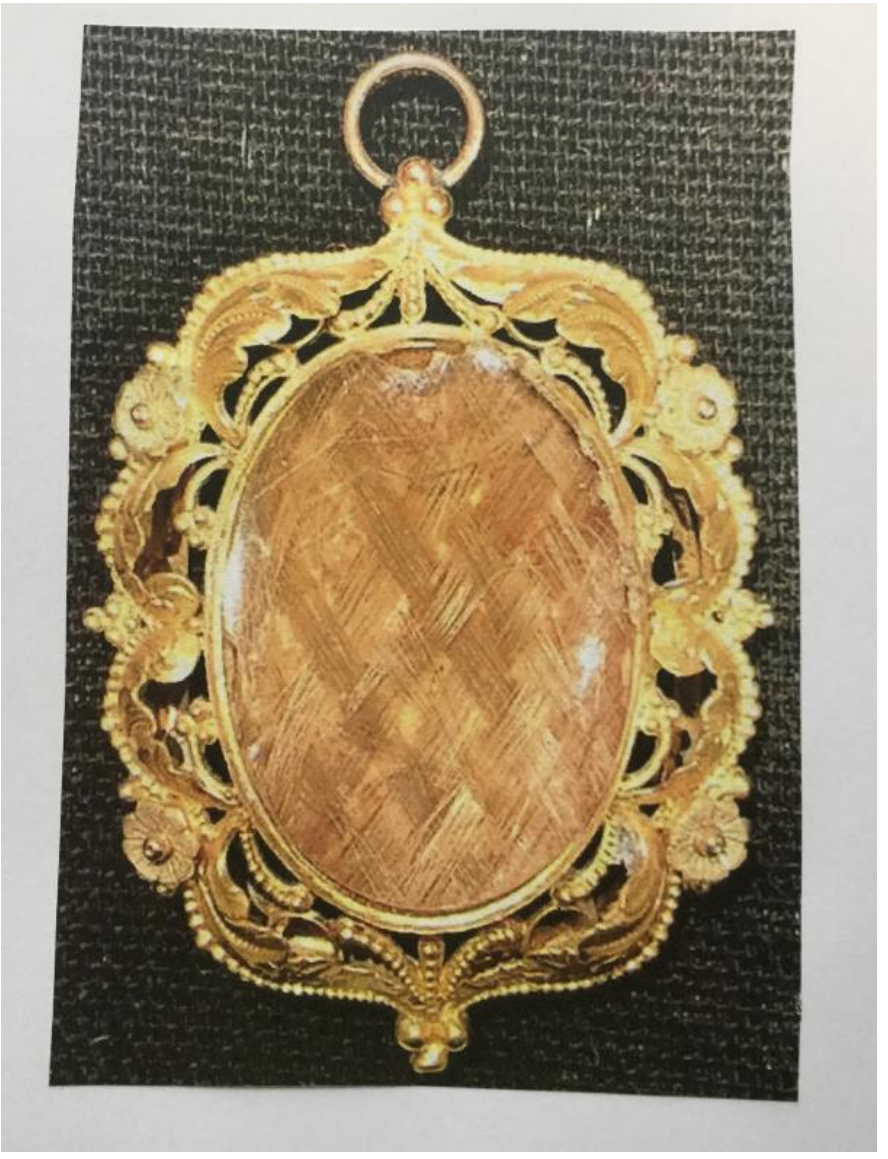

Figure 1 : Optical view (3x) of the medallion.

\section{MATERIAL AND METHODS}

We can distinguish individual hairs on the colour photograph of the corpus of the medallion (Figure 2). They are lumped together, by beams of about 15-20 hairs ; each beam is arranged in a global squared armure-like fashion. The figure indicates also the locations where metallic frame and glass samples are taken.

This article is published under the terms of the Creative Commons Attribution License 4.0 Author(s) retain the copyright of this article. Publication rights with Alkhaer Publications. Published at: http://www.ijsciences.com/pub/issue/2020-06/

DOI: 10.18483 /ijSci.2335; Online ISSN: 2305-3925; Print ISSN: 2410-4477 


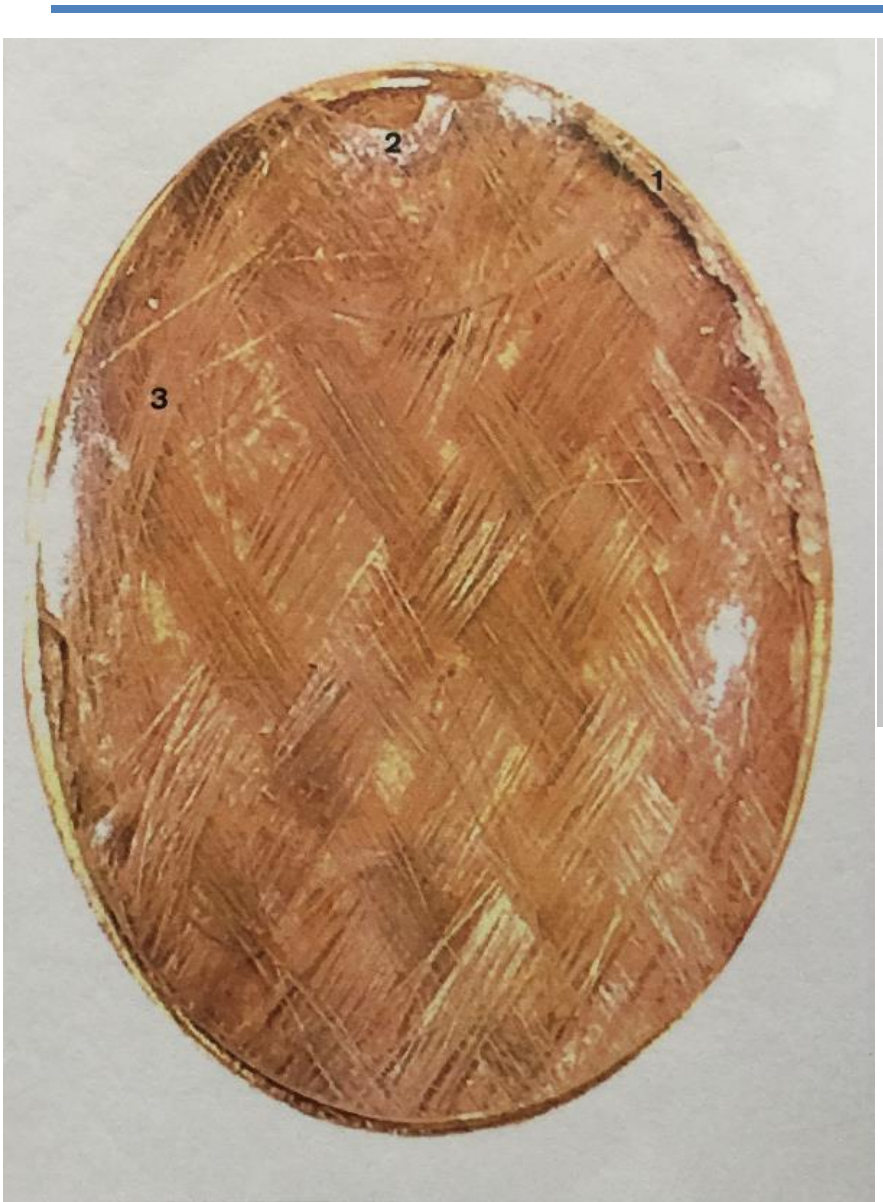

Figure 2: Optical view (5x) of the central part of the medallion, released from its metallic frame. 1, 2 and $\mathbf{3}$ indicate the locations where the metallic support, the bulding glass (in a part previously broken) and the hairs (under the glass) were taken.

We know by the owner that the medallion was established from the succession of the Duchess de Berry (1798-1870). Initially, the medallion constituted the main part of a bracelet.

Samples taken, with sterile blades, from two medallion parts (and thirteen hairs of the beam indicated) are loaded on dedicated scotch-tapes, itselves located on the platine of the electron microscope (Figure 3) for further optical, SEM and EDX analyses.
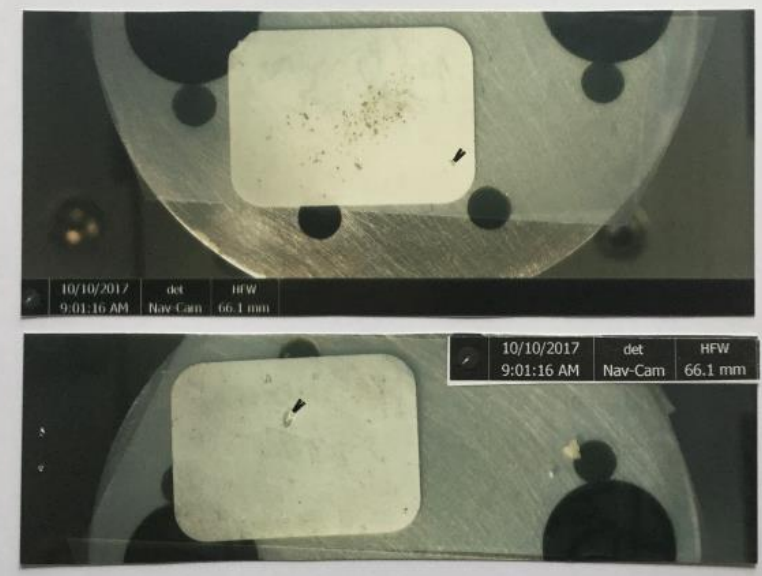

Figure 3 : Optical photographs (3x) of samples of metallic frame (above photograph) and of the glass (below photograph), located on the platine of the SEM ; arrow points indicate samples studied by SEM-EDX.

The SEM apparatus used is the FEI model Quanta FEG (an environmental apparatus). Elemental analyses were achieved using EDX, the SEM microscope being equipped with a probe model $\mathrm{X}$ flash 6/30 ; LFD (Large Field Detector) procedure was used. Each elemental analysis is given in the form of a spectrum, with kiloelectrons/Volts (ke/V) on the abscissa and elemental peak heights (cps/eV) in ordinates.

Genomic DNA was extracted from two hairs using a standard method (0.5M EDTA, sarcosyl $20 \%$ and proteinase $\mathrm{K} 10 \mathrm{mg} / \mathrm{ml}$ ) and purified using a commercial kit (NucleoSpin ${ }^{+}$Kit ; Macherey-Nagel) according to the manufacturer's instructions. From these extracted genomic DNAs, we obtained the mitochondrial-DNA (mt-DNA) sequence intervals for HVR1 and HVR2 (HyperVariable Regions 1 and 2) by PCR (Polymerase Chain Reaction) with primers F15971 and R16410 and with primers L15 and H484, respectively (Lucotte et al. , 2015). PCR products were purified from agarose gel. Both strands of the amplified mt-DNA fragments removed were directly sequenced (by the Big Dye Terminator Cyle sequencing kit; Applied Biosystems).

\section{RESULTS AND DISCUSSION}

In the present section, we give results concerning SEM-EDX analyses about the composition of the metallic frame, of the glass and of the hairs.

\section{Metallic frame}

The metallic composition of the frame sample studied (Figure 4) shows that it is constituted of gold (97.2\%) and copper (2.8\%) only. This highly elevated proportion of gold testifies that the medallion is a 
very precious object.

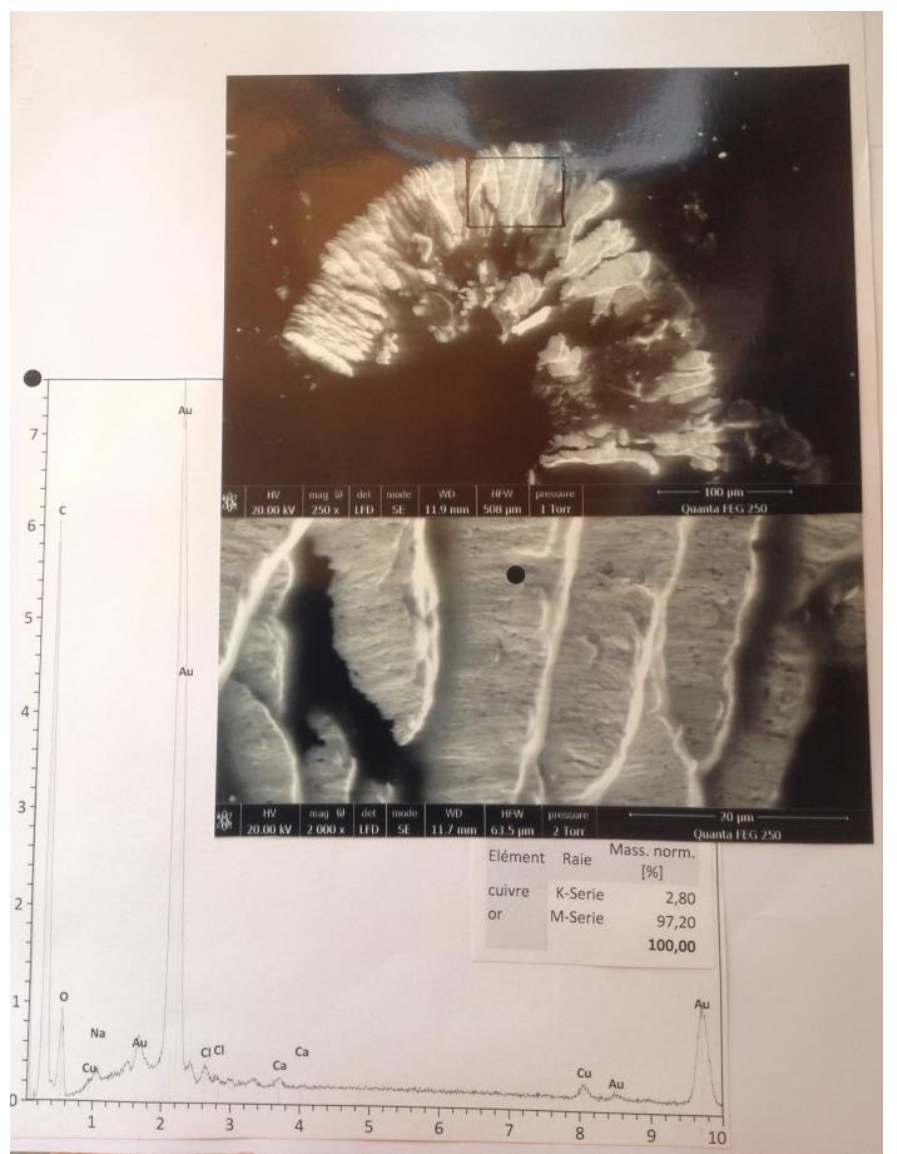

Figure 4 : SEM-EDX analysis of the metallic frame. Upper photograph : SEM photograph (in LFD, 250x) of the corresponding sample in the previous photograph indicated by an arrow point (the rectangle area is magnified in the below photograph). Lower photograph : SEM photograph (in LFD, 2000x) of the rectangle area in the above photograph (the black point indicates the location where elemental analysis is realized). Below : the spectrum at the black point. $\mathrm{C}$ : carbon ; $\mathrm{O}$ : oxygen ; $\mathrm{Cu}$ (two peaks) : copper ; $\mathrm{Na}$ : sodium ; $\mathrm{Au}$ (five peaks) : gold ; $\mathrm{Cl}$ (two peaks) : chlorine ; $\mathrm{Ca}$ (two peaks) : calcium. Insert : metallic composition of the frame sample.

\section{Glass}

The SEM photograph of the glass sample studied (a thin micro-scale of vitrous material, with cut bridges) shows that it is of glass (Figure 5). Its elemental composition, that corresponds to a main silicium peak with an annex aluminium peak (with traces of sulphur, that may confer the yellow colour to the glass observed) and with components of sodium, potassium (their oxides are the meltings) and calcium (its oxide is a stabilizer), confirms that it is well of glass.

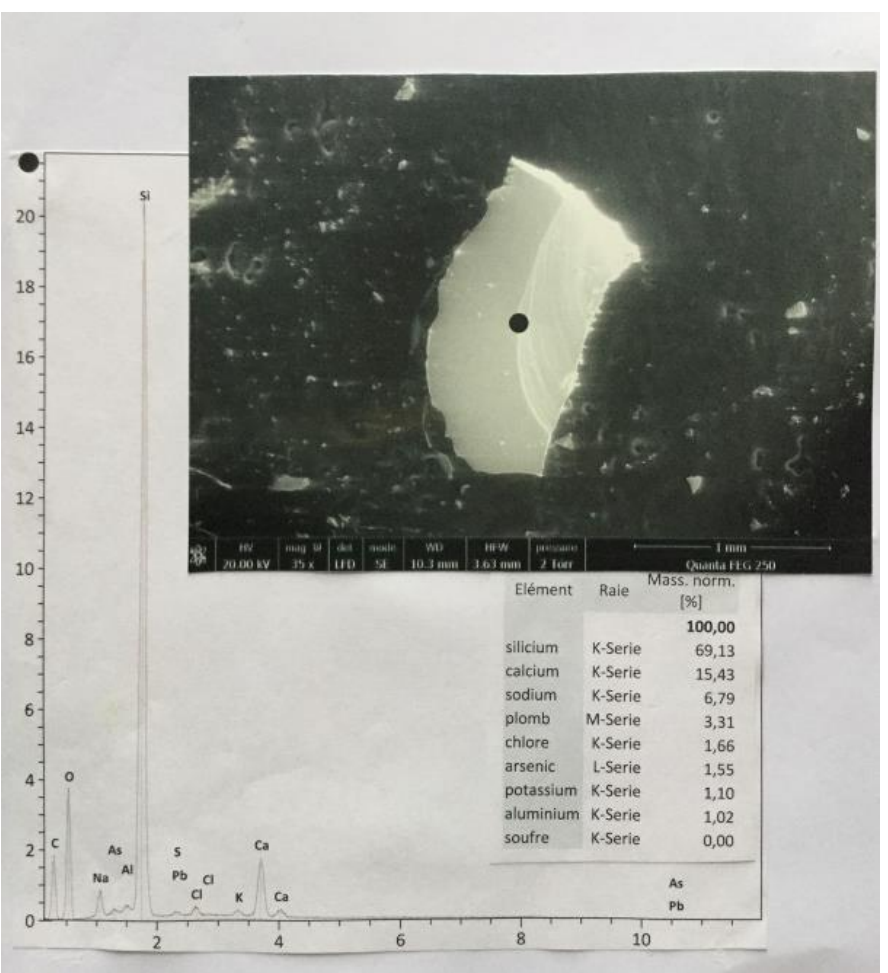

Figure 5 : SEM-EDX analysis of the glass. Above : SEM photograph (in LFD, 35x) of the corresponding sample of the lower figure 3 photograph. Below: the spectrum at the black point. $\mathrm{C}$ : carbon; $\mathrm{O}$ : oxygen ; $\mathrm{Na}$ : sodium ; As (two peaks) : arsenic ; $\mathrm{Al}$ : aluminium ; $\mathrm{Si}$ : silicium ; $\mathrm{Pb}$ (two peaks) : lead ; $\mathrm{S}$ (traces) : sulphur ; $\mathrm{Cl}$ (two peaks) : chlorine ; $\mathrm{K}$ : potassium ; $\mathrm{Ca}$ (two peaks) : Calcium. Insert : normalized composition of the glass sample.

As supplementary material in the composition, we note the presences of lead $(3.3 \%)$, chlorine $(1.7 \%)$ and arsenic (1.6\%). By these distinctive features the glass look-likes to some form of stained-glass window, that increases again the precious character of the object.

\section{Hairs}

Figure 6 shows an optical view of hairs numbers 1, 1' , 2 and 3. Their colour, as for the other hairs taken, are blond-red (or, more exactly, ash blond). We know that this special hair colour was that of MarieAntoinette when she was young. 


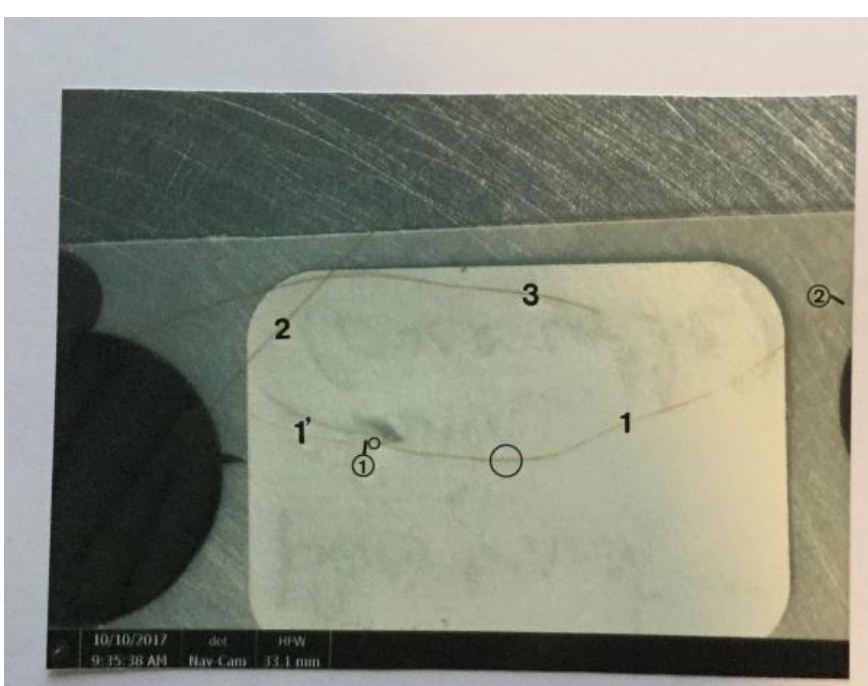

Figure 6 : Optical view (3x) of hairs 1, 1', 2 and 3, loaded on a scotch-tape. (1) and (2) : the two extremities of hair fragment number 1 (magnified on figure 9) ; the little circle area concerning the junction between hairs $\mathbf{1}$ and $\mathbf{1}$ 'is magnified on figure 7 . The circled area in the middle part of $\mathbf{1}$ is magnified on the lower SEM photograph of figure 8 .

The SEM photograph of Figure 7 shows the junction area between hairs $\mathbf{1}$ and $\mathbf{2}$. The bridge linking these two hairs is almost entirely constituted of chlorine ; we know that hypochlorid acid $(\mathrm{HClO})$ was already used at this time (that of the de Berry Duchess) for her fungicide properties.

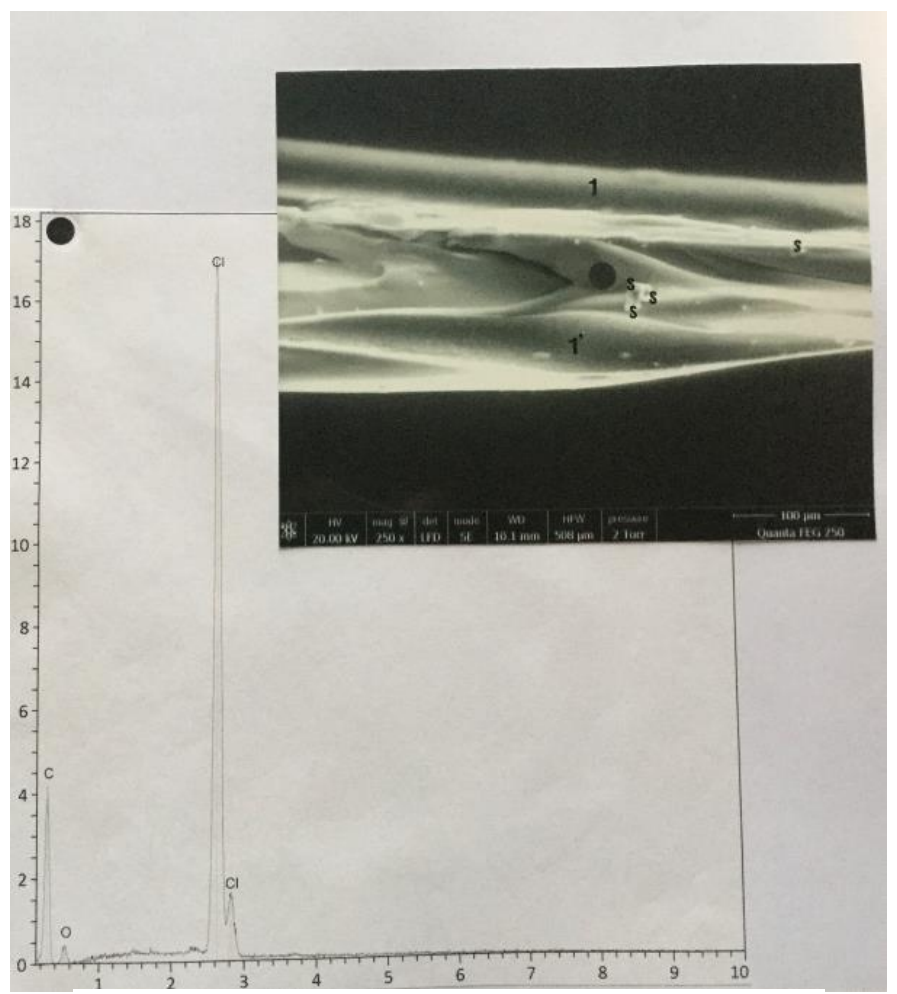

Figure 7 : Above : SEM photograph (in LFD, 250x) of the area of junction between hairs $\mathbf{1}$ and $\mathbf{1}^{\prime}$ (the black point indicates the bridge between $\mathbf{1}$ and $\mathbf{1}$ '). S : micro-crystals of salt. Below : spectrum at the black point. $\mathrm{C}$ : carbon ; $\mathrm{O}$ : oxygen ; $\mathrm{Cl}$ (two peaks) : chlorine.

In the junction area between the two hairs, we can also distinguish at least four micro-grains of salt $(\mathrm{NaCl})$; this product is well-known (since the Antiquity) for its conservative properties. Hypochlorid acid and salt were common products used by the"men-of-art" at this time to sterilize hair preparations.

The lower SEM photograph of Figure 8 shows the middle part area of hair number 1, taken as an example. We can see on its surface regularly spaced rows of scales (so it is well an hair). The hair surface is without mineral deposits, that indicating that it was carefully cleaned. Mean distances between scale rows (upper photograph of figure 8) are between 6.5 and $8.7 \mu \mathrm{m}$, a characteristic of human hairs.

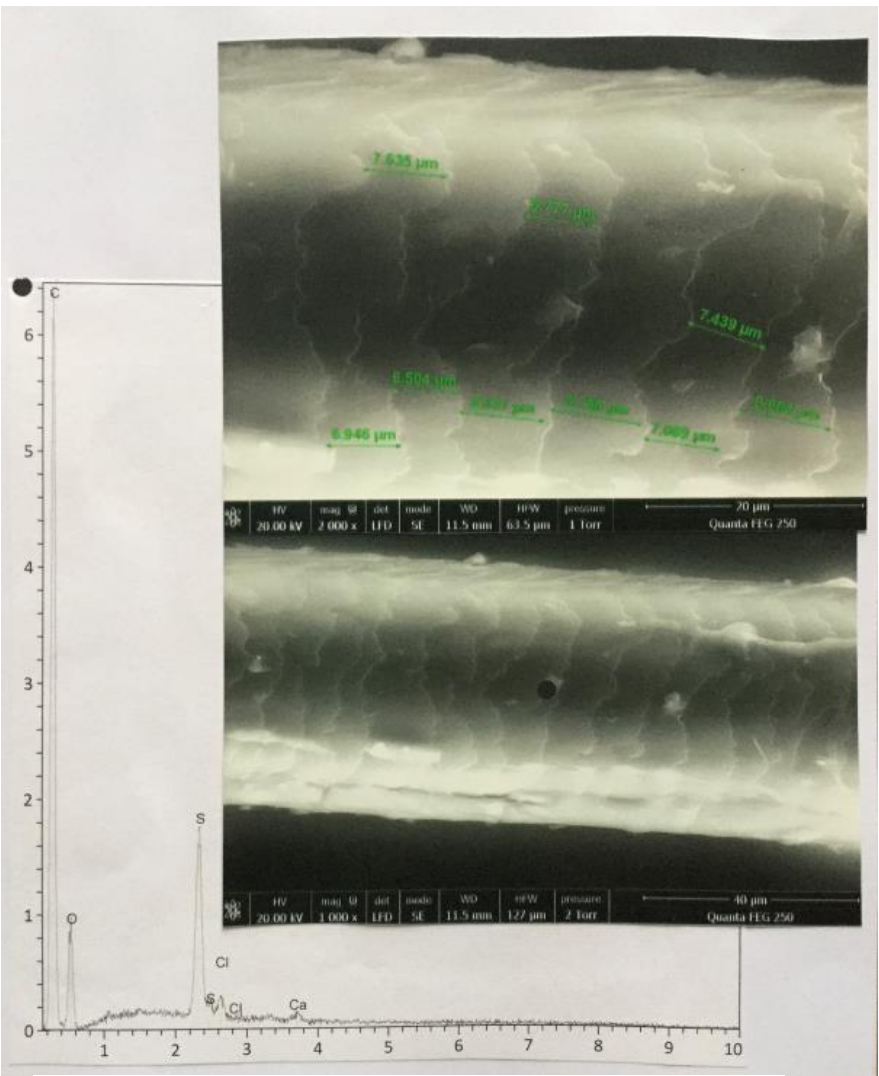

Figure 8 : The middle part of hair number 1. Lower photograph :SEM photograph (in LFD, 1000x) of this part. Upper photograph : SEM photograph (2000x) showing scale rows; distances between rows are in $\mu \mathrm{m}$. Below : spectrum at the black point. $\mathrm{C}$ : carbon ; $\mathrm{O}$ : oxygen ; $\mathrm{S}$ (two peaks) : sulphur ; $\mathrm{Cl}$ (two peaks) : chlorine; $\mathrm{Ca}$ : calcium.

The thickness of hair number $\mathbf{1}$ in its middle part is of $48.5 \mu \mathrm{m}$, a value near that of the mean value $(=47.8$ 
$\mu \mathrm{m})$ of the thirteen hairs studied. Part of that thickness is probably due to the fact that these hairs were dessicated during the preparation (the main thickness of a normal human hair is about $60-80 \mu \mathrm{m}$ ) ; this lower value can possibly explained if they are woman's hairs, the mean thickness being lower in women than in men.

SEM photographs of Figure 9 shows the both extremities of hair number 1. Like those of other hairs studied, they establish that it is a cut hair, the abrupt and rectangular aspect of the cuts indicates that they were cut by scissors (rather than by razor, which gives more acute extremities).
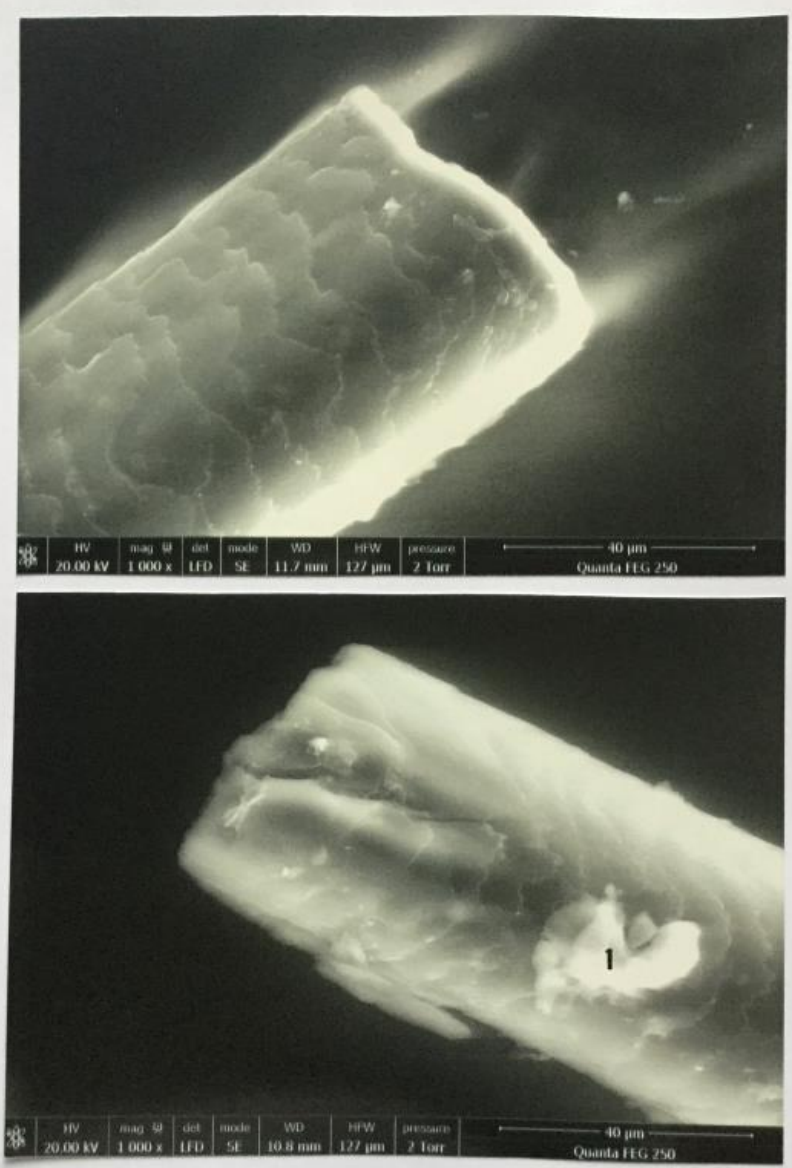

Figure 9 : SEM photographs (in LFD, 1000x) of extremity (2) (above) and (1) (below) of hair number 1. The number 1 of the lower photograph indicates a first voluminous deposit on the hair surface.

SEM photographs of Figures 9 and 10 show two relatively big deposits ( 1 and 2 )

of matter near the (1) extremity of hair number $\mathbf{1}$. They are mainly constituted of organic matter (carbon and oxygen), and represent residues of the glue that linked the hairs together in beams. This glue is a starch glue, starch grains - probably of from being regognizable by their forms and dimensions (see upper SEM photograph of Figure 10) - in the deposit 2.

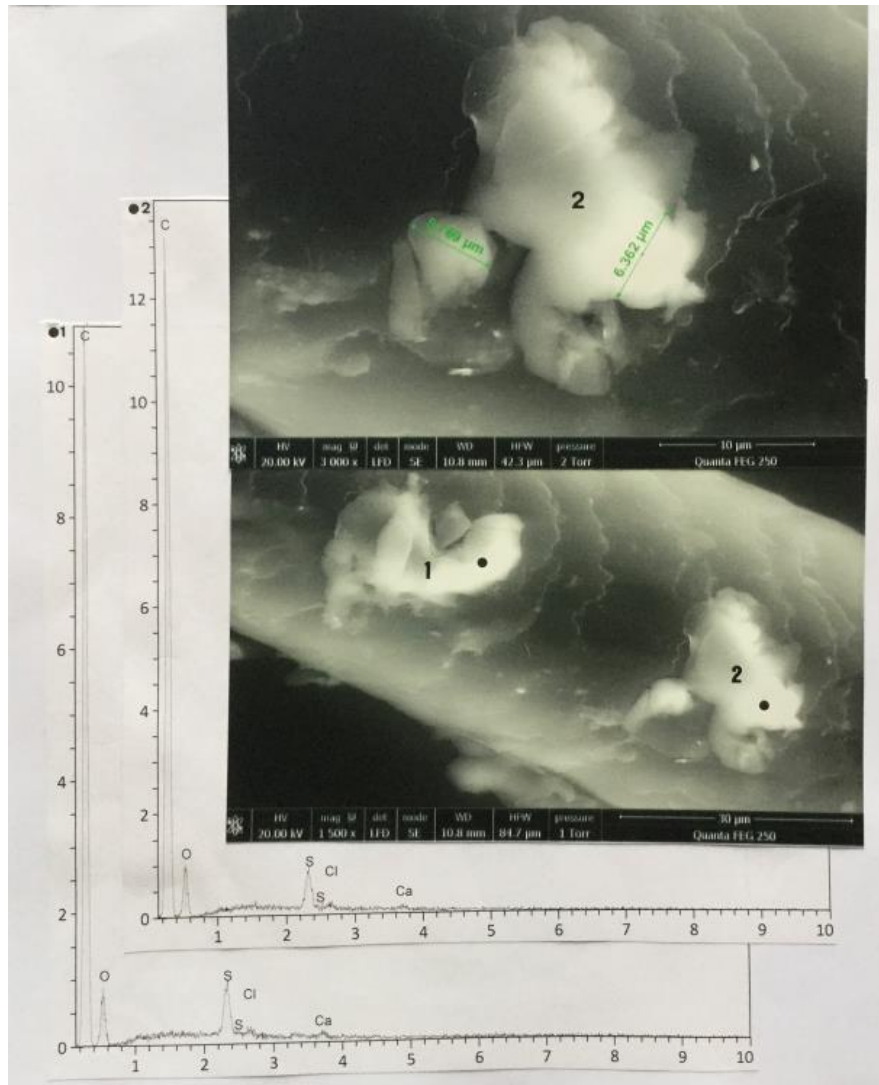

Figure 10 : Lower photograph : SEM photograph (in LFD, 1500x) of deposits numbers 1 and 2. : SEM photograph (in LFD, 3000x) of deposit 2 ; lengths of two starch grains are in $\mu \mathrm{m}$. Below : spectras of deposits 1 and 2. $\mathrm{C}$ : carbon; $\mathrm{O}$ : oxygen; $\mathrm{S}$ (two peaks) : sulphur ; $\mathrm{Cl}$ : chlorine ; $\mathrm{Ca}$ : calcium.

Genomic DNA was extracted from hair number $\mathbf{6}$ (the longest) and the corresponding HVR1 and HVR2 mt-DNA sequences were obtained.

There is no mutation in the HVR1 sequence, and four mutations (152C, 194T, 263G and 315.1C) in the HVR2 sequence. Identical results were obtained from hair number 7 .

These mutations, and the corresponding mt-DNA haplogroup, are the same as those previously found for two independent sets of authentic hairs of Louis XVII (Lucotte et al. , 2015 ; Lucotte et al. , 2019), initially found (Jehaes et al. , 2001) in some present day living related to Marie-Antoinette.

The corresponding haplogroup is a rare sub-clade of mt-DNA haplogroup $\mathrm{H}$.

\section{Aknowledgments}

We thank the initial owner of the medallion for financial support, and experts of the Coutau-Bigarie 
Company (Paris) for facilities. This study is included in our research program of genetic investigations developed at the Institute of Molecular Anthropology concerning royal families in France ; it is also our own contribution to the activity of the "MarieAntoinette Association".

\section{References}

1. E. Jehaes, H. Pfeiffer K. Toprak, R. Decorte, B. Brinkmann and J.J. Cassiman (2001). Mitochondrial DNA analysis of the putative heart of Louis XVII, son of Louis XVI and MarieAntoinette. European Journal of Human Genetics, 9 : 185190.

2. G. Lucotte, T. Thomasset and C. Crépin (2015). The mitochondrial DNA mitotype of Louis XVII (1785-1795?). International Journal of Sciences, 4 (11) : 10-18.

3. G. Lucotte, C. Crépin and T. Thomasset (2019). The Ychromosome STRs profile of Louis XVII (1785-1795?). International Journal of Sciences, 8 (02) : $44-75$. 